\title{
SEBARAN DAN KEBIASAAN MAKAN BEBERAPA JENIS IKAN DI DAERAH ALIRAN SUNGAI KAPUAS, KALIMANTAN BARAT
}

\author{
Susilo Adjie dan Emmy Dharyati \\ Peneliti pada Balai Riset Perikanan Perairan Umum, Mariana-Palembang \\ Teregistrasi I tanggal: 22 Mei 2009; Diterima setelah perbaikan tanggal: 15 Juni 2009; \\ Disetujui terbit tanggal: 16 Oktober 2009
}

\begin{abstract}
ABSTRAK
Sungai Kapuas merupakan sungai terbesar di Kalimantan Barat, memiliki tipe ekologi yang kompleks mulai dari hulu sampai ke muara dan memiliki keanekaragaman hayati tinggi terutama keanekaragaman ikannya. Penelitian ini bertujuan untuk mendapatkan informasi tentang sebaran jenis ikan, pakan alami, dan habitat dari beberapa jenis ikan. Metode penelitiannya adalah dengan survei dan observasi selama tiga kali pada bulan April, Juli, dan Desember 2007 di daerah aliran Sungai Kapuas bagian tengah, hulu, sampai stasiun sekitar Danau Sentarum, Leboyan, Danau Empangau, Jongkong, dan, Sungai Sibau Hulu. Pengambilan data dilakukan pada 12 stasiun pengamatan. Parameter yang diambil adalah diversitas dan sebaran ikan, pakan alami (food habits), habitat, dan kualitas air. Hasil penelitian menunjukkan bahwa sebaran ikan semah (Tor spp.) di hulu sungai yang berarus deras, sedangkan ikan ringo (Datnoides microlepis) tersebar dari kawasan Semitau, Danau Sentarum, sampai Danau Empangau. Ikan tabirin (Belodonthicthys dinema), hampir tersebar di semua stasiun pengamatan, dan ikan entukan (Thinnichthys thynoides) paling dominan di danau. Berdasarkan pada pengamatan pakan alami, ikan semah merupakan ikan omnivora, sedangkan tabirin, dan ringo merupakan ikan karnivora. Ikan entukan sebagai ikan pemakan plankton (plankton feeder).
\end{abstract}

KATAKUNCl: $\quad$ sebaran, kebiasaan makan ikan, habitat, daerah aliran Sungai Kapua

\section{PENDAHULUAN}

Luas perairan umum di Propinsi Kalimantan Barat mencapai dua juta ha yang terdiri atas danau, rawa, dan sungai. Salah satunya adalah Sungai Kapuas yang merupakan sungai terbesar di Kalimantan Barat dan terpanjang di Indonesia, yaitu 1.080 km (Sutikno, 1981). Daerah aliran Sungai Kapuas mempunyai tipe ekologi yang sangat kompleks, namun secara garis besar ada tiga tipe yang penting, yaitu 1) tipe perairan berarus deras sampai sedang, bukan merupakan daerah banjiran, pada umumnya berbatu, dan sekeliling sungai merupakan daerah perkebunan atau perladangan, 2) tipe perairan yang merupakan rawa banjiran, arus tenang, banyak terdapat anak sungai, di sekeliling sungai merupakan hutan rawang, dan 3 ) tipe perairan yang dipengaruhi oleh pasang surut air laut (Utomo et al., 1991).

Sungai Kapuas memiliki keanekaragaman hayati yang cukup tinggi terutama keanekaragaman jenis ikannya yang kurang lebih 200 spesies (Dudley, 1996). Di antara jenis-jenis ikan tersebut banyak terdapat ikan-ikan bernilai ekonomis seperti ikan belida (pipih) (Chitala spp.), betutu (Oxyleotris marmorata), jelawat (Leptobarbus hoeveni Blkr), dan arwana (Scleropages spp.). Aktivitas penangkapan di Sungai Kapuas banyak terdapat di daerah aliran sungai bagian tengah yang memiliki karakteristik habitat berupa rawa banjiran. Pada daerah aliran
Sungai Kapuas juga terdapat Taman Nasional Danau Sentarum yang merupakan salah satu kawasan konservasi dengan luas 132.000 ha (Anonimus, 2007). Hutan rawa di Sungai Kapuas mempunyai peran yang penting bagi kelestarian sumber daya perikanan yaitu sebagai daerah pemijahan, naungan, dan tempat mencari makanan (Utomo \& Asyari, 1999).

Potensi sumber daya perikanan perairan umum cenderung menurun, bahkan beberapa jenis ikan menjadi langka, antara lain ikan babat (Datniodes quadrifsciatus), arwana, belida, dan tabirin. Menurut Pollnac \& Malvestuto (1991) bahwa daerah aliran Sungai Kapuas mulai tampak dipengaruhi tekanan ekologis dari sektor pertanian dan industri. Berdasarkan pada hasil penelitian tahun 2006 (Utomo et al., 2006), ditemukan lebih dari 120 jenis ikan ekonomis penting yang terdapat di daerah aliran Sungai Kapuas, dan keanekaragaman hayati ikan di daerah tengah yang banyak terdapat rawa banjiran lebih tinggi dari daerah hulu. Demikian juga biomassa ikan pada daerah tengah lebih tinggi pada rawa banjiran. Hasil penelitian tersebut dapat memberikan indikasi adanya penurunan potensi sumber daya dari tahun 1996. Namun, informasi tentang sebaran jenis ikan dan kebiasaan pakan ikan terbatas. Dalam upaya pengelolaan sumber daya perikanan sangat diperlukan informasi tentang sebaran jenis ikan, kebiasaan pakan alami dan ekologis habitat tempat hidup ikan. 
Penelitian ini bertujuan untuk mendapatkan informasi tentang sebaran jenis ikan, kebiasaan pakan alami, dan ekologis habitat tempat hidup ikan. Informasi ini diharapkan dapat dipergunakan oleh pemerintah daerah bagi pengelolaan sumber daya daerah aliran Sungai Kapuas.

\section{BAHAN DAN METODE}

Pengumpulan contoh di lapangan dilakukan pada bulan April, Juli, dan Desember 2007 pada 12 stasiun pengamatan di daerah aliran Sungai Kapuas bagian tengah, antara kawasan Semitau dan Danau Sentarum, Leboyan, Danau Empangau, Jongkong, dan Sungai Sibau Hulu. Data sebaran jenis ikan diperoleh dengan melakukan pengambilan contoh dari hasil tangkapan nelayan pada beberapa tipe ekosistem. Ikan yang tertangkap dicatat, ukuran panjang $(\mathrm{cm})$ dan bobot $(\mathrm{g})$. Untuk mengetahui kebiasaan pakan alami ikan, dilakukan analisis saluran pencernaan ikan dari ikan tabirin, ringo, entukan, dan semah. Contoh usus ikan diberi label dimasukkan ke dalam kantong plastik yang berisi larutan formalin $10 \%$, dan dibawa ke laboratorium untuk dianalisis. Jasad isi usus diidentifikasi dengan mengikuti Needham \& Needham (1963) dan Pennak (1978). Analisis isi usus dengan menggunakan metode indeks bagian terbesar (index of preponderance) dari Natarajan dan Jhingran (Effendie, 1992) dengan rumus sebagai berikut:

$$
\mathrm{li}=\frac{\mathrm{VixOi}}{\sum \mathrm{VixOi}} \times 100 \%
$$

di mana:

$$
\begin{aligned}
& \mathrm{V}_{\mathrm{i}} \quad=\text { persentase volume satu macam } \\
& \text { makanan (\%) } \\
& \mathrm{O}_{\mathrm{i}} \quad=\text { persentase frekuensi kejadian satu } \\
& \text { macam makanan (\%) } \\
& \Sigma \mathrm{V}_{\mathrm{i}} \mathrm{xO}_{\mathrm{i}}=\text { jumlah } \mathrm{V}_{\mathrm{i}} \mathrm{xO}_{\mathrm{i}} \text { dari semua macam } \\
& \text { makanan (\%) } \\
& \mathrm{I}=\text { index of preponderance }
\end{aligned}
$$

Posisi sebaran ikan dicatat nama daerahnya dan posisi geografi dengan menggunakan alat GPS. Selain itu, juga dilakukan pengisian blanko isian hasil tangkapan yang dibagikan pada nelayan atau enumerator untuk mengetahui sebaran ikan. Ikan yang tertangkap bila belum diketahui jenisnya diidentifikasi berdasarkan pada Kottelat et al. (1993); Gustiano (2003) dan Weber \& De Beaufort (1916). Pengamatan kualitas air dengan parameter dan metodenya berpedoman pada buku petunjuk APHA, (1986); Barnes \& Man (1980); Boyd (1979); Wetzel \& Likens (1979). Pengambilan contoh air untuk pengukuran suhu, $\mathrm{pH}$ dengan $\mathrm{pH}$-meter, $\mathrm{CO}_{2}, \mathrm{O}_{2}, \mathrm{BOD}$, alkalinitas, $\mathrm{PO}_{4} \mathrm{NO}_{3} \mathrm{NO}_{2}, \mathrm{COD}, \mathrm{N}-\mathrm{NH}_{3} \mathrm{DHL}$, TSS, dan pengukuran kecerahan dengan secchi disk, sedangkan kecepatan arus dengan cara mengapungkan benda ringan dalam air sungai dan mencatat waktu yang dibutuhkan pada jarak tertentu diukur dengan alat stop wacth (Tabel

\begin{tabular}{|c|c|c|c|}
\hline \multirow{2}{*}{ Parameter } & \multirow{2}{*}{ Satuan } & \multicolumn{2}{|c|}{ Alat dan cara yang digunakan } \\
\hline & & Metode & Peralatan \\
\hline Suhu & ${ }^{\circ} \mathrm{C}$ & Insitu & Termometer \\
\hline Kecerahan & $\mathrm{cm}$ & Insitu & Piring sechi \\
\hline $\mathrm{DHL}$ & $\mu \mathrm{S} / \mathrm{cm}$ & Insitu & SCT meter \\
\hline & $\mathrm{pH}$ unit & Insitu & $\mathrm{pH}$ universal indicator \\
\hline Karbondioksida & $\mathrm{mg} / \mathrm{L}$ & Insitu, titrimetri metode Winkler & $\mathrm{NaOH}$ sebagai titrant \\
\hline Oksigen terlarut & $\mathrm{mg} / \mathrm{L}$ & Insitu, titrimetri metode Winkler & Larutan thiosulfat sebagai titrant \\
\hline Alkalinitas & $\mathrm{mg} / \mathrm{L}$ & Insitu, titrimetri metode Winkler & Larutan $\mathrm{H}_{2} \mathrm{SO}_{4}$ sebagai titrant \\
\hline BOD & $\mathrm{mg} / \mathrm{L}$ & Insitu, titrimetri metode Winkler & Larutan thiosulfat sebagai titrant \\
\hline $\mathrm{PO}_{4}$ & $\mathrm{mg} / \mathrm{L}$ & Vanadate molibdate & Spetrophotometric \\
\hline $\mathrm{NO}_{3}^{4}$ & $\mathrm{mg} / \mathrm{L}$ & Nessler & Spetrophotometric \\
\hline $\mathrm{NO}_{2}^{\circ}$ & $\mathrm{mg} / \mathrm{L}$ & Nessler & Spetrophotometric \\
\hline COD & $\mathrm{mg} / \mathrm{L}$ & Titrimetri metode Dichromate reflux & $\begin{array}{l}\text { Standard ferrous ammonium sulfat } \\
\text { sebagai titrant }\end{array}$ \\
\hline $\mathrm{N}-\mathrm{NH}_{3}$ & $\mathrm{mg} / \mathrm{L}$ & Phenate & Spetrophotometric \\
\hline Kecepatan arus & $\mathrm{km} / \mathrm{jam}$ & $\begin{array}{l}\text { Insitu, mengapungkan benda ringan } \\
\text { dalam air sungai dan mencatat waktu } \\
\text { yang dibutuhkan pada jarak tertentu }\end{array}$ & Stop wacth \\
\hline Posisi geografi & $\begin{array}{l}\text { derajat, } \\
\text { menit, detik }\end{array}$ & & GPS \\
\hline
\end{tabular}
1).

Data sebaran jenis ikan dan pakan alami ikan, kualitas air dan habitat diuraikan secara deskriptif dan dibuat dalam bentuk peta berdasarkan pada posisi geografi, sehingga diketahui pola penyebarannya.

Tabel 1.

Parameter kualitas air yang diukur dan analisis 


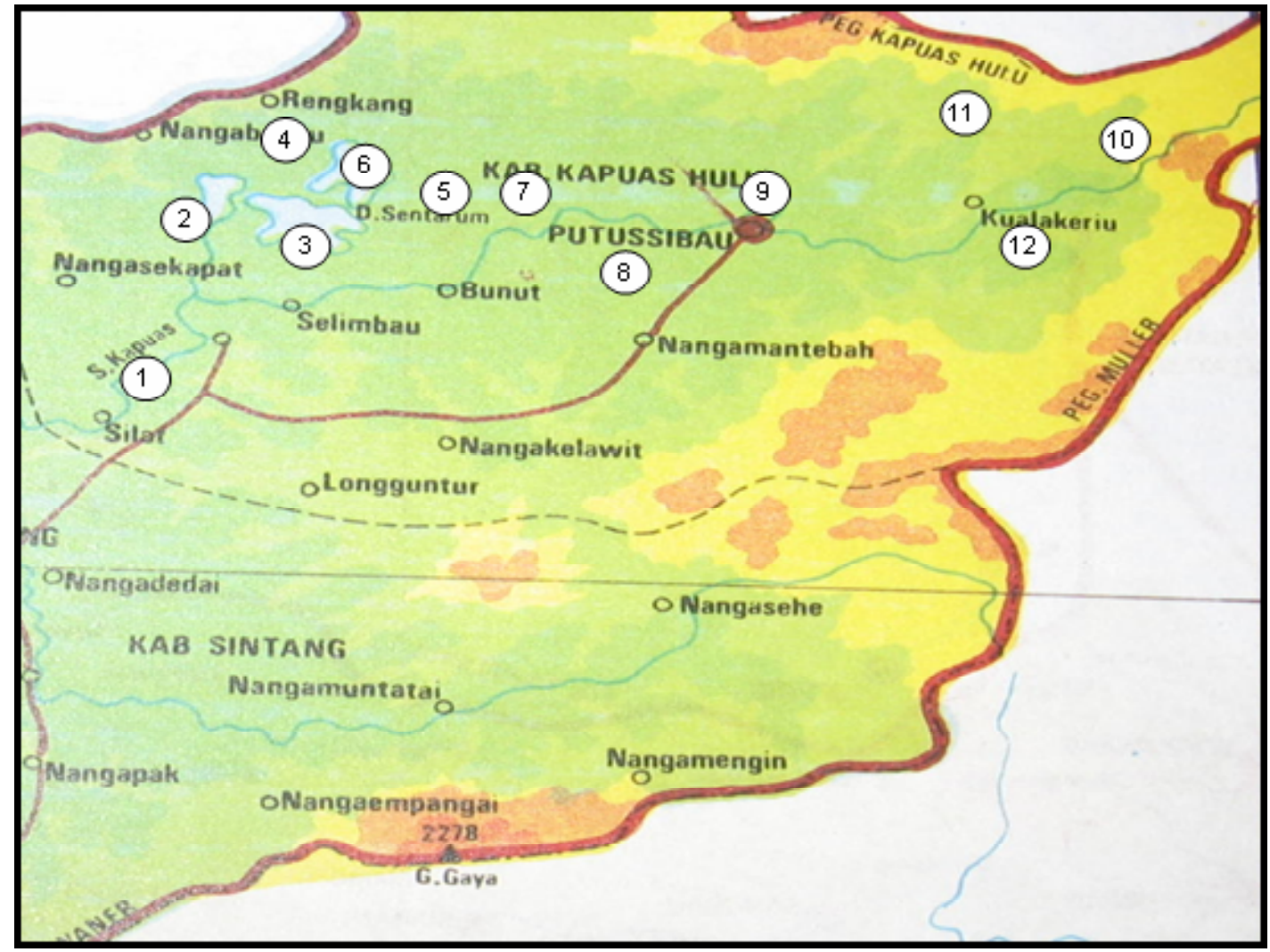

Keterangan: STT = daerah tengah daerah aliran Sungai Kapuas; STH = daerah hulu daerah aliran Sungai Kapuas

I\% STT 1: Semitau dan sekitarnya İ\% STT 7: Nanga Lemboyan dan sekitarnya

I\% STT 2: Nanga Tengkidap $\quad$ Ï\% STH 8:

Ï\% STT 3: $\quad$ Kenelang dan sekitarnya $\quad$ Ï\% STH 9:

I\% STT 4: $\quad$ Bukit Tekenang sekitarnya $\quad$ i\% STH 10:

I\% STT 5: $\quad$ Semangit $\quad$ \% STH 11:

I\% STT 6: $\quad$ Samar Indah $\quad$ I\% STH 12:

Nanga Lemboyan dan se
Jongkong dan sekitarnya

Empangau dan sekitarnya

Sibau Hulu dan sekitarnya

Embaloh dan sekitarnya

Nanga Potan/Jots

Gambar 1. Peta lokasi penelitian di daerah aliran Sungai Kapuas, Kalimantan Barat.

\section{HASIL DAN BAHASAN}

Lokasi pengambilan contoh penelitian yaitu di daerah tengah dan hulu Sungai Kapuas, stasiun penelitian ditetapkan ada 12 stasiun penelitian yaitu Semitau, Nanga Tengkidap, Kenelang, Bukit Tekenang, Samar Indah, Semangit, Leboyan (daerah tengah Sungai Kapuas), Jongkong, Danau Empangau, Sibau Hulu, Embaloh, dan Nanga Potan/Jots (daerah hulu Sungai Kapuas) (Gambar 1). Jenis ikan yang diamati baik sebaran dan kebiasaan pakan adalah ikan tabirin, ringo, entukan, dan semah.

\section{SEBARAN IKAN}

Sebaran ikan tabirin, ringo, entukan, dan semah, pada kawasan Semitau, Danau Sentarum, Danau Empangau sampai hulu Sungai Kapuas (Tabel 2). Ikan tabirin tersebar di 9 stasiun penelitian, ikan ukuran besar ditangkap dengan alat pukat atau pancing (rabai), bahkan dengan alat pancing khusus untuk ikan tabirin yaitu acar yang terbuat dari logam berwarna putih berbentuk ikan yang diberi mata pancing di sekelilingnya, sehingga ikan tabirin yang menyangka umpan dan memakannya. Ikan ringo banyak ditemui dalam jumlah banyak di stasiun Samar Indah, Leboyan, Nanga Kenelang, Bukit Tekenang, dan Danau Empangau, karena pada stasiun ini pada umumnya kecepatan arus rendah dan tenang, sehingga ikan ringo dapat hidup dan pakan alami berupa udang-udang kecil banyak terdapat pada perairan yang relatif tenang. Pada stasiun Jongkong, Semitau, dan Sibau Hulu sangat sedikit dijumpai, karena pada habitat sungai yang berkecepatan arus lebih dari $5 \mathrm{~km} / \mathrm{jam}$ ikan ringo sulit mendapatkan pakan alami. Ikan ringo saat ini sudah dijadikan ikan hias yang dikirim ke Jakarta dan diekspor ke Malaysia dan Singapura. Hal ini dikhawatirkan akan terjadi penangkapan ikan ringo dalam jumlah besar, yang pada akhirnya membuat sumber daya ikan tersebut berkurang bila tidak ada pembatasan penangkapan. Di daerah Bunut kawasan Kapuas hulu, ikan ringo dengan ukuran besar banyak ditemukan, sedangkan 
pada daerah lainnya sudah sulit ditemukan. Ikan ringo yang ditangkap nelayan banyak yang berukuran kecil yaitu berkisar 3-6 cm, sedangkan yang berukuran besar 18-25,3 cm.

Ikan entukan yang tertangkap oleh nelayan dengan bermacam ukuran dari yang kecil sampai besar, berkisar 26,3-39 cm dengan bobot 170-260 g, banyak tertangkap di 9 stasiun dan terbanyak pada stasiun Samar Indah, Leboyan, dan Empangau. Stasiun ini berada di danau-danau dan merupakan habitat ikan entukan. Alat tangkap yang digunakan nelayan bermacam-macam yaitu jala, bubu waring, dan jermal (bubu jermal). Ikan entukan dapat ditangkap tergantung tingginya air. Habitat tertangkapnya ikan entukan terdapat pada bagian tengah dan tepi danau oxbow lake dan juga pada pinggir sungai banyak terdapat tumbuhan. Ikan entukan dominan dapat ditemukan di bagian tengah daerah aliran Sungai Kapuas.

Ikan semah banyak ditemukan di hulu Kapuas sesuai dengan habitatnya yaitu airnya berarus deras. Ekosistemnya berada dalam kondisi yang baik dan ini tidak terlepas dari keberadaan hutan lindung yang berada dalam Taman Nasional Betung Kerihun. Ikan semah di stasiun Sibau Hulu, Embaloh, dan Nanga
Potan banyak di temui dalam jumlah banyak dengan berbagai ukuran. Alat tangkap yang digunakan nelayan bermacam-macam antara lain jala, bubu waring, dan jermal (bubu jermal).

\section{HABITAT}

\section{Ikan Tabirin}

Ikan tabirin ini merupakan ikan putih (white fish) yang hidup di lapisan bawah pada sungai-sungai yang dalam. Habitat ikan tabirin berada di tepi danau-danau (Danau Sentarum), sungai, dan muara sungai yang agak rimbun yang ditumbuhi feripiton. Habitat tersebut berada pada kondisi dengan kecepatan arus rendah, berkisar antara 0,84-3,5 km/jam, suhu air berkisar antara $27-31^{\circ} \mathrm{C}$, kadar $\mathrm{O}_{2}$ terlarut berkisar antara 3,8$7,9 \mathrm{mg} / \mathrm{L}$, dan nilai pH berkisar antara 5-6,5. Menurut Pescod (1973); NTAC (1968) kualitas air seperti ini cukup baik untuk mendukung kehidupan ikan dan organisme pakan ikan.

\section{Ikan Ringo}

Habitat ikan ringo berada pada tepi sungai dan danau yang merupakan hutan rawa yang banyak di tumbuhi perdu dengan kecepatan arus $0,84-3,5 \mathrm{~km} /$

Tabel2. Sebaran ikan tabirin, ringo, entukan, dan semah di daerah aliran Sungai Kapuas bagian tengah dan hulu, Kalimantan Barat

\begin{tabular}{|c|c|c|c|c|c|c|}
\hline \multirow{2}{*}{ Stasiun } & \multirow{2}{*}{\multicolumn{2}{|c|}{$\begin{array}{l}\text { Posisi } \\
\text { GPS }\end{array}$}} & \multicolumn{4}{|c|}{ Jenis ikan } \\
\hline & & & Tabirin & Ringo & Entukan & Semah \\
\hline Semitau & & & - & $\mathrm{x}$ & $\mathrm{x}$ & - \\
\hline Nanga Tengkidap & $\begin{array}{l}N \\
S\end{array}$ & $\begin{array}{l}00^{\circ} 40^{\prime} 26 " 8 \\
11^{\circ} 59^{\prime} 20^{\prime \prime} 3\end{array}$ & $x$ & $x x$ & $x$ & - \\
\hline Nanga Kenelang & $\begin{array}{l}\mathrm{N} \\
\mathrm{S}\end{array}$ & $\begin{array}{l}00^{\circ} 46 ’ 25 " 7 \\
101^{\circ} 58^{\prime} 44^{\prime \prime} 5\end{array}$ & $x x$ & $x x$ & $x x$ & - \\
\hline Bukit Tekenang & $\begin{array}{l}N \\
S\end{array}$ & $\begin{array}{l}00^{\circ} 50^{\prime} 22 " 2 \\
112^{\circ} 03^{\prime} 48^{\prime \prime} 6\end{array}$ & $x$ & $x x$ & $x x$ & $x$ \\
\hline Samar Indah & $\begin{array}{l}N \\
S\end{array}$ & $\begin{array}{l}00^{\circ} 51^{\prime} 32 " 0 \\
102^{\circ} 07^{\prime \prime} 46^{\prime \prime} 97\end{array}$ & $x x x$ & $x x x$ & $x x x$ & - \\
\hline Semangit & $\begin{array}{l}N \\
S\end{array}$ & $\begin{array}{l}00^{\circ} 50^{\prime} 52 " 4 \\
112^{\circ} 14^{\prime} 83^{\prime \prime} 0\end{array}$ & $x x$ & - & $x x$ & - \\
\hline Leboyan & $\begin{array}{l}N \\
S\end{array}$ & $\begin{array}{l}00^{\circ} 54^{\prime} 47^{\prime \prime} 7 \\
112^{\circ} 21^{\prime} 24^{\prime \prime} 1\end{array}$ & $x x x$ & $x x x$ & $x x x$ & - \\
\hline Jongkong & $\begin{array}{l}N \\
S\end{array}$ & $\begin{array}{l}00^{\circ} 39^{\prime} 47^{\prime \prime} 1 \\
112^{0} 17^{\prime \prime} 02^{\prime \prime} 9\end{array}$ & $\mathrm{x}$ & $\mathrm{x}$ & $x x$ & - \\
\hline Empangau & $\begin{array}{l}N \\
S\end{array}$ & $\begin{array}{l}00^{\circ} 43^{\prime} 07^{\prime \prime} \\
112^{\circ} 22^{\prime} 48^{\prime \prime 2}\end{array}$ & $x x$ & $x x$ & $x x x$ & - \\
\hline Sibau Hulu & $\begin{array}{l}N \\
E\end{array}$ & $\begin{array}{l}112^{\circ} 59^{\prime} 570 \\
01^{\circ} 02^{\prime} 548^{\prime \prime}\end{array}$ & $x$ & $x$ & - & $x x$ \\
\hline Embaloh & $\begin{array}{l}N \\
E\end{array}$ & $\begin{array}{l}01^{\circ} 25^{\prime} 47^{\prime \prime} \\
112^{\circ} 36^{\prime} 66^{\prime \prime}\end{array}$ & - & - & - & $\mathrm{x}$ \\
\hline Nanga Potan & $\begin{array}{l}\mathrm{N} \\
\mathrm{E}\end{array}$ & $\begin{array}{l}01^{\circ} 03^{\prime} 997^{\prime \prime} \\
113^{\circ} 02^{\prime} 018^{\prime \prime}\end{array}$ & - & - & - & $x x x$ \\
\hline
\end{tabular}

Keterangan: banyak ditemui : xxx; sedang : xx; sedikit : x; tidak ditemukan : - 
jam, suhu air antara $27-31^{\circ} \mathrm{C}$, kadar $\mathrm{O}_{2}$ terlarut berkisar 3,8-7,9 mg/L dan nilai $\mathrm{pH}$ berkisar 5-6,5. Menurut Pescod (1973); NTAC (1968) kualitas air seperti ini cukup baik untuk mendukung kehidupan ikan dan organisme pakan ikan.

\section{Ikan Entukan}

Habitat ikan entukan terdapat pada bagian tengah dan tepi danau oxbow lake, dan juga pada tepi sungai yang banyak ditumbuhi tumbuhan. Habitat tersebut berada pada kondisi dengan kecepatan arus rendah berkisar antara 0,84-3,5 km/jam seperti di daerah aliran Sungai Kapuas kawasan Danau Sentarum dengan keadaan air tenang mengalir sangat lambat dan kecerahan berkisar 19-120 cm yang menandakan habitatnya baik dan terawat serta tidak banyak pencemaran. Sekitar danau banyak ditumbuhi tumbuhan dan perifiton. Kualitas air yang didapat yaitu nilai suhu air antara $27-31^{\circ} \mathrm{C}$, kadar $\mathrm{O}_{2}$ terlarut berkisar 3,8-7,9 mg/L dan nilai $\mathrm{pH}$ berkisar 5-6,5. Menurut Pescod (1973); NTAC (1968) kualitas air seperti ini cukup baik untuk mendukung kehidupan ikan dan organisme pakan ikan. Alat tangkap yang digunakan nelayan bermacam-macam jala, bubu waring, dan jermal (bubu jermal). Ikan entukan dapat ditangkap tergantung tingginya air.

\section{Ikan Semah}

Karakteristik daerah aliran Sungai Kapuas bagian hulu sebagaimana yang digambarkan oleh Welcomme (1985) tidak berbeda dengan daerah aliran sungai bagian hulu lainnya di Indonesia, yang merupakan daerah rhithron (rhithron zone). Wilayah perairan ini mempunyai ciri yang berbeda dengan perairan bagian hilir (potamon zone). Daerah aliran sungai bagian hulu ditandai dengan sifat aliran air yang deras, terdapat banyak bebatuan mulai dari yang berukuran kecil, sedang (grave), sampai yang besar (boulder). Dasar perairannya didominansi oleh pasir bebatuan dengan kandungan lumpur yang sedikit, air sangat jernih dan bersih, serta tepi kiri dan kanan badan air terdapat hutan dan pepohonan. Karena topografi dari hulu sungai yang menurun, sehingga terjadi arus yang kuat mencapai 9,9-10,1 km/jam (Tabel 3). Sedangkan nilai suhu air rata-rata $24,5^{\circ} \mathrm{C}$, karena kawasan hulu Kapuas pada habitat ikan semah berada topografi yang tinggi. Kadar $\mathrm{O}_{2}$ terlarut berkisar $8,24 \mathrm{mg} / \mathrm{L}$ dan nilai pH berkisar 7. Menurut Pescod (1973); NTAC (1968) kualitas air seperti ini cukup baik untuk mendukung kehidupan ikan dan organisme makanan ikan. Di samping ekologi dan ekosistemnya berada dalam kondisi yang baik, dan ini tidak terlepas dari keberadaan hutan lindung yang berada dalam Taman Nasional Betung Kerihun.

\section{KEBIASAAN MAKAN}

Komoditas ikan tidak beda dengan hewan-hewan lainnya yaitu membutuhkan cukup makanan untuk hidup dan pertumbuhannya, sedangkan organisme yang dimakan disesuaikan dengan mekanisme perkembangan dari alat pencernaannya (Lagler et al., 1962). Pakan sendiri merupakan mekanisme utama yang mempengaruhi penyebaran ikan secara ekologis, khususnya ikan air tawar (Macpherson, 1981 dalam Tjahjo, 1991).

\section{Ikan Tabirin}

Berdasarkan pada analisis pakan ikan tabirin dan indexs of preponderance diketahui bahwa ikan tabirin mempunyai pakan utama berupa ikan $96,71 \%$ dengan pakan tambahannya berupa udang $2,86 \%$, dan pakan pelengkapnya berupa detritus $0,42 \%$ (Tabel 4). Berdasarkan pada hasil analisis tersebut, maka ikan tabirin termasuk dalam golongan ikan karnivora. Dari 38 ekor contoh ikan tabirin hanya ditemukan 29 ekor yang saluran pencernaannya berisi pakan, sedangkan 9 ekor yang lainnya lambung atau ususnya kosong.

\section{Ikan Ringo}

Hasil pengamatan isi usus ikan ringo terdapat pada Tabel 4. Ikan ringo yang berukuran kecil 3-6 cm pada ususnya terdapat udang kecil $88 \%$ sebagai pakan utama selebihnya cyclop, rotifer, dan coscinodiscus. Ikan ringo yang berukuran besar 18-25,3 cm dalam usunya terdapat ikan $98 \%$ dan detritus hanya $2 \%$. Berdasarkan pada analisis dari laboratorium pada lambung dan isi usus ikan ringo dapat disimpulkan termasuk dalam golongan karnivora.

\section{Ikan Entukan}

Ikan entukan yang tertangkap oleh nelayan memiliki ukuran antara 20-35 cm. Isi usus ikan terdapat $65 \%$ phytoplankton dan 35\% zooplankton. Dari analisis dapat disimpulkan bahwa ikan entukan yang tertangkap di daerah aliran Sungai Kapuas pada danau-danau dapat digolongkan ke dalam kelompok ikan pemakan plankton (plankton feeder) (Tabel 4).

\section{Ikan Semah}

Hasil pengamatan isi usus ikan semah memperlihatkan bahwa makanan alami pada ikan semah yang berukur kecil $(11-16 \mathrm{~cm})$ terdiri atas cacing nematoda $87,5 \%$ dan ikan semah yang berukuran besar $(27-44 \mathrm{~cm})$ terdiri atas lumut mencapai $80 \%$ (Tabel 4). Setiap individu ikan semah yang tertangkap 


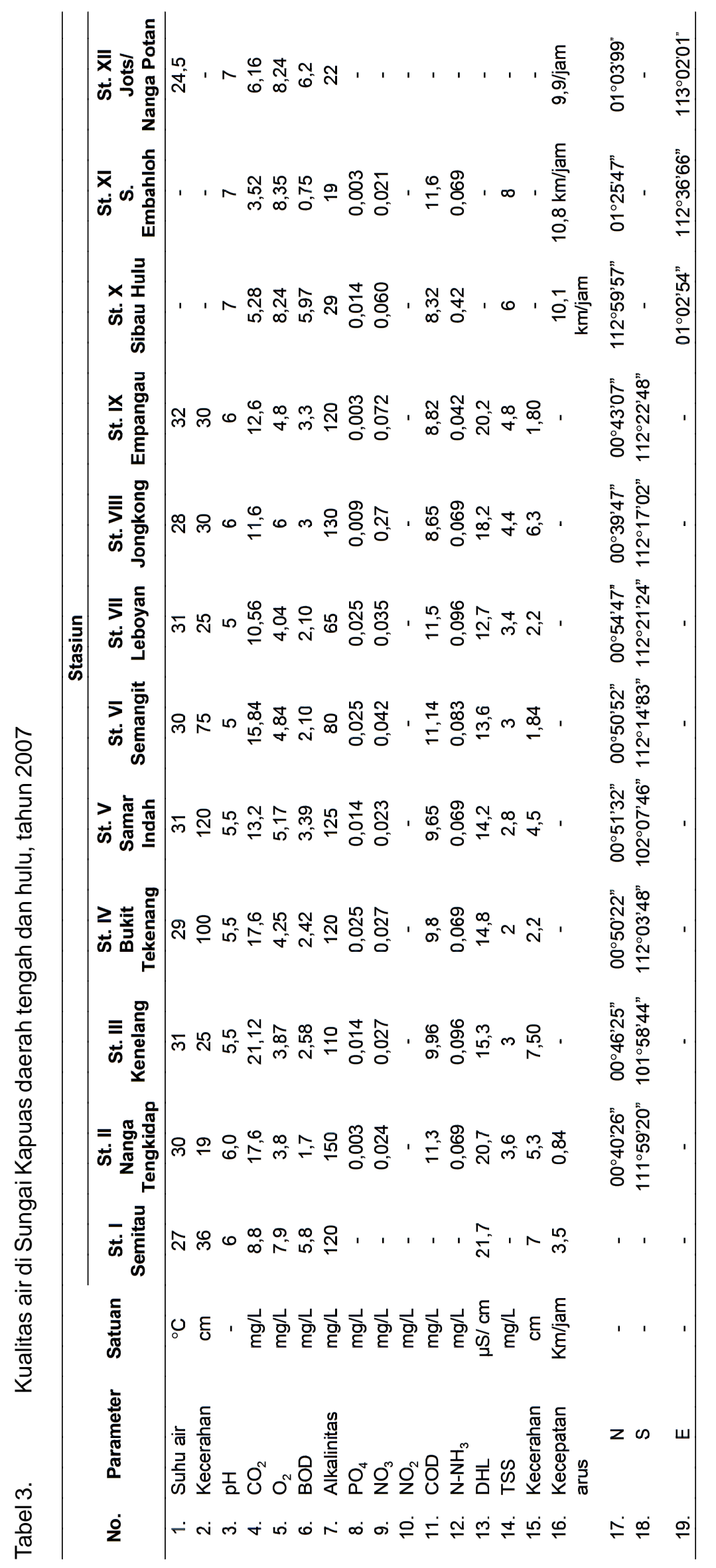


Tabel 4. Hasil analisis organisme makanan ikan

\begin{tabular}{|c|c|c|c|c|c|c|c|}
\hline \multirow{4}{*}{ No. } & \multirow{4}{*}{ Jenis pakan alami } & \multicolumn{6}{|c|}{ Index of preponderance (\%) } \\
\hline & & \multicolumn{6}{|c|}{ Jenis ikan } \\
\hline & & \multicolumn{2}{|c|}{ Ringo } & \multirow{2}{*}{ Tabirin } & \multirow{2}{*}{ Entukan } & \multicolumn{2}{|c|}{ Semah } \\
\hline & & kc & bs & & & kc & sd \\
\hline 1. & Lumut & - & - & - & - & - & 80 \\
\hline 2. & Cacing nematoda & - & - & - & - & 87,5 & 12,37 \\
\hline 3. & Serangga & - & - & - & - & 10 & 5,97 \\
\hline 4. & Sisa tumbuhan (debris) & - & - & - & - & - & 1,27 \\
\hline 5. & Plankton & - & - & 0,001 & - & - & - \\
\hline 6. & Udang kecil & 88 & - & 2,860 & - & 0,39 & - \\
\hline 7. & Cyclops & 10 & - & - & - & - & - \\
\hline 8. & Rotifer & 1 & - & - & - & - & \\
\hline 9. & Detritus & 1 & 2 & 0,425 & 30 & - & - \\
\hline 10. & Ikan & - & 98 & 96,714 & - & - & - \\
\hline 11. & Phytoplankton & - & - & - & 44 & - & - \\
\hline 12. & Zooplankton & - & - & - & 20 & - & - \\
\hline 13. & Protozoa & - & - & - & 3 & - & - \\
\hline 14. & Material tumbuhan & - & - & - & 3 & - & - \\
\hline
\end{tabular}

Keterangan: $\mathrm{kc}=$ ukuran kecil; $\mathrm{bs}=$ ukuran besar; $\mathrm{sd}=$ ukuran sedang

dengan ukuran yang seragam tidak menunjukkan perbedaan yang nyata dalam komposisi jenis makanan yang dicerna. Nilai indexs of preponderance tertinggi terdapat pada jenis pakan alami berupa lumut, yaitu $80 \%$. Di samping itu, pakan alami ikan semah berupa bentuk hancuran dari buah-buahan dengan nilai $\mathrm{IP}=1,27 \%$, sedangkan pakan alami berupa fitozooplankton dan cacing nematoda terdapat dalam jumlah sedikit. Dari analisis isi usus ikan semah dapat disimpulkan bahwa ikan semah yang tertangkap di daerah aliran Sungai Kapuas bagian hulu dapat digolongkan ke dalam kelompok ikan omnivor dengan referensi pakan yang cenderung mengarah ke herbivor, seperti lumut yang menempel di bebatuan dan buah-buahan hutan yang jatuh ke air (buah kepayang yang banyak tumbuh di tepi Sungai Sibau dan Embaloh).

\section{KESIMPULAN}

1. Sebaran ikan semah di hulu sungai yang berarus deras. Ikan ringo tersebar dari kawasan Semitau, Danau Sentarum, sampai Danau Empangau dengan habitat hutan dan rawang, dapat ditemui pada 9 stasiun penelitian dalam jumlah sedikit.

2. Habitat ikan tabirin tersebar di semua stasiun penelitian, banyak terdapat pada habitat pinggiran Danau Sentarum dan juga pada pinggir sungai dan muara-muara sungai yang agak rimbun yang di tumbuhi peripiton. Ikan entukan paling dominan di danau-danau dan terdapat di tengah dan tepi danau oxbow lake dan juga pada tepi sungai banyak ditumbuhi tumbuhan.
3. Berdasarkan pada pengamatan pakan alami, ikan semah merupakan ikan omnivora sedangkan ikan tabirin dan ringo merupakan ikan karnivora. Ikan entukan mempunyai kebiasaan makan sebagai ikan pemakan plankton.

\section{PERSANTUNAN}

Kegiatan dari hasil riset biologi beberapa jenis ikan bernilai penting di daerah aliran Sungai Kapuas, Kalimantan Barat, T. A. 2007, di Balai Riset Perikanan Perairan Umum-Mariana, Palembang.

\section{DAFTAR PUSTAKA}

Anonimus. 2007. Buku Informasi Taman Nasional Danau Sentarum. Balai Taman Nasional Danau Sentarum, Kalimantan Barat.

APHA. 1986. Standard Methods for the Examinations of Water and Wastewater. APHA Inc. Washington D. C.

Barnes, R. S. K. \& K. H. Mann. 1980. Fundamentals of Aquatic Ecosystem. Blackwell Scientific Publication. Oxford. $229 \mathrm{pp}$.

Boyd, C. E. 1979 Water Quality in Warmwater Fishpond. Auburn University. Dept. of Fisheries and Aquacultures. Fish Edition. Alabama. U. S. A. 359 pp. 
Dudley, R. G. 1996. The Fisheries of the Danau Sentarum Wildlife Reserve, West Kalimantan Indonesia. A. W. B. Bogor-Indonesia. 1-10.

Effendie, A. 1992. Aspek Ekologi Perairan Dalam Analisis Dampak Lingkungan. Latihan Amdal. Bogor.

Gustiano, R. 2003 Taxonomy and Phylogeny of Pangasidae Catfishes from Asia (Ostariophysi, Siluriformes). Katholieke Universiteit Leuven. Laboratory of Comparative Anatomy and Biodiversity. Belgium. 296 pp.

Kottelat, M., A. J. Whitten, S. N. Kartikasari, \& S. Wirjoatmodjo. 1993. Freshwater Fishes of Western Indonesia and Sulawesi (Ikan Air Tawar Indonesia Bagian Barat dan Sulawesi). Periplus EditionsProyek EMDI. Jakarta.

Lagler, K. F. 1962. Freshwater Fishery Biology. Second Edition W. M. C. Brown Company. Dubuque. Lowa. 421 pp.

Needham, J. G. \& D. R. Needham. 1963. A Guide to the Study of Freshwater Biology. $15^{\text {th }}$ Edition. Holden Day Inc. Sanfrancisco. 108 pp.

NTAC. 1968. Water Quality Criteria. FWPCA. Washington D. C. 234 pp.

Pennak, R. W. 1978. Fresh Water Invertebrates of the United States. Second Edition. Jhon Wiley and Sons. New York. 783 pp.

Pescod, M. B. 1973. Investigation of Rational Efflaent and Strem Standars for Countries. ATT. Bangkok. $59 \mathrm{pp}$.

Pollnac, R. B. \& S. P. Malvestuto. 1991. Biological and sosio economic condition for the development and management of riverine fishery resources on Musi and Kapuas Rivers. Prosiding Temu Karya IImiah Pengelolaan Sungai dan Perairan Umum Bagi Perikanan. Pusat Penelitian dan Pengembangan Perikanan. Jakarta. Pros.Puslitbangkan/No.22/1992.67-80.
Sutikno. 1981. Status perikanan perairan umum Kalimantan Barat. Prosiding Seminar Perairan Umum. Pusat Penelitian dan Pengembangan Perikanan. Jakarta. 107-114.

Tjahjo, D. W. H. 1991. Kebiasan pakan komunitas ikan di Waduk Jatiluhur. Bulletin Penelitian Perikanan Darat. Balai Penelitian Perikanan Air Tawar. Bogor. 10 (2): 1-8.

Utomo, A. D., Z. Nasution, \& M. F. Sukadi. 1991. Potensi sumber daya perikanan daerah aliran Sungai Kapuas, Kalimantan Barat. Prosiding Temu Karya IImiah Pengelolaan Sungai dan Perairan Umum Bagi Perikanan. Pusat Penelitian dan Pengembangan Perikanan. Jakarta. Pros. Puslitbangkan/No.22/1992. 67-80.

Utomo, A. D. \& Asyari. 1999. Peran ekosistem hutan rawa air tawar bagi kelestarian sumber daya perikanan di Sungai Kapuas, Kalimantan Barat. Jurnal Penelitian Perikanan Indonesia. Pusat Penelitian dan Pengembangan Perikanan. Jakarta. $\mathrm{V}(3): 1-13$.

Utomo, A. D., S. Adjie, N. Muflikah, \& A. Wibowo. 2006 Distribusi jenis ikan dan kualitas perairan di Bengawan Solo. Jurnal Penelitian Perikanan Indonesia. Pusat Riset Perikanan Tangkap. Badan Riset Kelautan dan Perikanan. 12 (2): 89-100.

Weber, M. \& De Beaufort. 1916. The Fishes of the Indo-Australian Archipelago. E. J. Brill Ltd. Leiden. I-XII.

Welcomme, R. L. 1985. River fisheries. FAO Fish. Tech. Paper (262). Rome. 330 pp.

Wetzel, R. G. \& G. E. Linkens. 1979. Limnology. Analisys W. B. Sounders Company. Philadelphia. London. Toronto. 367 pp. 